\title{
Family Physicians' Competency and Satisfaction about Emergency Services in Family Practice Centers, Egypt
}

\begin{abstract}
:
Background: Emergency situations are not out of the ordinary in an active family practice. Actually, $90 \%$ of the cases seen in emergency room can be handled perfectly by a qualified family physician. Objectives: This study aimed to evaluate Family physicians' perceived competency in emergency skills and satisfaction on emergency services in family practice centers. Methods: This study is a cross-sectional analytic study; it was conducted between January and November 2017, in family medicine department. All family postgraduate physicians (master or medical doctorate) in the study period were included. Sample recruited was 35 family physicians. Data were collected using a self-administered questionnaire to determine the physicians' perceived competency and satisfaction on dealing with emergency cases. Results: Physicians' age mean (SD) was 31.7 (4.7) years, most of them were females $(85.7 \%)$, only $8.6 \%$ were qualified with master degree. Half $(51.4 \%)$ did not attend Basic life support course. Also $80.0 \%$ and $77.1 \%$ did not attend Advanced Cardiac Life Support or Advanced Trauma Life Support course respectively. Males reported higher level of competency (mean rank=27.30), $\mathrm{p}=0.028$. Physicians who had master degree reported higher competency in performing emergency skills (mean rank=32.83), $\mathrm{P}=0.009$. Physicians who had attended ACLS ( $<1$ year) reported highest score of perceived level of competency in performing skills (mean rank=31.0), $\mathrm{P}=0.015$. Conclusion: There are deficits in perceived competency in performing emergency skills among family physicians, and high dissatisfaction with current emergency services. Also there is need for more training courses as BLS, ACLS, and ATLS for family physicians.
\end{abstract}

Keywords: Emergency care, PHC, Satisfaction, Training, Competency.

Introduction: Primary health care centers provide care to an expansive number of medically underserved Egyptians. Primary health care (PHC) is defined by the World Health Organization (WHO) as essential health care made universally accessible to individuals and families in the community by means acceptable to them through their full participation and at a cost the community and the country can afford. Primary Health Care (PHC) encompasses services as ; family planning, maternity care, child care, dental care, health educational services, communicable diseases control, emergency care and environmental health services. ${ }^{(1)}$ Since 1997, Health Sector Reform Program was the main concern of the Ministry of Health and Population(MOHP) in Egypt.

The issue of "quality" figures into all three components of the reform program strategy. 1. implementing an integrated family practice care model; 2.developing a new social insurance financing mechanism through the establishment of a Family Health Fund (FHF); and 3) strengthening the role of the Ministry of Health

\footnotetext{
*Corresponding author: Email: hind_mikhail@yahoo.com
} 
and Population in a line with a facility accreditation program. It nullified its previous wellbeing offices maternal and child health centers and dispensaries and combined these services into PHC centers (PHCCs), which provide both curative and preventive aspect. $^{(2)}$ Primary healthcare centers (PHCCs) as often as possible are reached for emergency reasons and are relied upon to give basic and advanced life support during emergency circumstances. ${ }^{(3)}$

An emergency in the workplace setting can be tricky without satisfactory staff, support, tools, and protocols. In spite of the fact that numerous emergencies are not immediately life threatening, one risks the 'worst case scenario' happening if not sufficiently arranged. ${ }^{(4)}$ Several studies have demonstrated that emergency situations are not out of the ordinary in an active family practice/primary health care office. ${ }^{(3-4)}$ An emergency is "a sudden incident that necessitates urgent and appropriate management to treat its outcomes and evade its sequelae". (5)

Strengthening family practice centers to cover emergency public health needs can be made by applying the "revitalization of PHC approach" through (1) universal coverage, and equity; (2) participation of the community; (3) inter-sectoral collaboration; and (4) appropriate use of technology. ${ }^{(6)}$ Recent studies estimated some of factors that affect the provision of high quality emergency services at the primary care level. These are; good governance and collaboration among other health sector partners, sufficient health sector financing which would in turn result in adequate health infrastructure, availability of equipment, basic medicines and motivated efficient services. $^{(7-8)}$

Some of the emergencies can be managed completely at a family practice while others should be referred to hospital after initial management. The degree to which a patient ought to be overseen might be controlled by the level of seriousness of the condition, experience of the doctor and distance to the nearest hospital. ${ }^{(9)}$ Otherwise, absence of proper referral at PHC level could be the reason for health risk and imminent danger to life. The triage system must be adjusted to allow channeling of PHC patients to the appropriate level of care. It would be useful to create a standard letter that can be used when referring a patient to the appropriate level of care. ${ }^{(10)}$

Emergency medicine lies in the field of practice of family medicine because it is the integral part of all the medical, surgical, psychiatric, pediatric and other specialties. Emergency medicine is not, properly speaking, a discipline in its own 
right. In order to clarity its contents, we must dip into each and all of the known medical specialties, as well as into family medicine, which already unifies them all. ${ }^{(11)}$

Actually, $90 \%$ of the cases seen in emergency room can be handled perfectly by a well-trained qualified family physician using a well-organized training program including basic life support (BLS), Advanced Trauma Life support (ATLS), Advanced Cardiac Life support (ACLS) and so on. ${ }^{(11)}$ Data regarding Family physicians' satisfaction about emergency services, competency, and training in emergency skills in family practice centers, Suez Canal University, Egypt aren't available. Relevant information from health service providers, especially family physicians training and acquired skills, are very important to health care policymakers for improvement quality of patient care and providing effective and optimal management of the current services.

This study aimed to evaluate Family physicians' perceived competency regarding emergency skills and satisfaction about emergency services at the level of family practice centers.

\section{Methods:}

This study is a cross-sectional analytic study, it was conducted between January and November 2017, in the family medicine department; faculty of medicine; Suez Canal University in Ismailia city, Egypt. Target population: all family physicians in postgraduate studies of master or medical doctorate degrees during the study period, in the family medicine department, faculty of medicine, Suez Canal University, who fulfilled the inclusion criteria (work as family physician and recruited in postgraduate studies of family medicine) and agreed to take part in the study, we recruited them. Those who refused to participate in the study, not family physician, or not recruited to postgraduate studies were excluded from the study.

The study group was participated in the study; sample recruited all postgraduate family physicians (35 Physicians), data were collected during the scientific day of master and medical doctorate in the family medicine department by convenience sampling. Family physicians are working in nine family practice centers, which affiliated to Family medicine department, which are distributed in three geographical sectors. There are three centers in Ismailia city, two centers in Port Saied city and four centers in Suez city. 


\section{Tools of the study:}

The invited physicians filled a self-administered questionnaire which consisted of three parts:

Part (1): It contained personal data about physicians: age, gender, and qualification degree. Part (2): It was training level, previous experience, and courses. Part (3): It formed of three sections: A- perceived level of competence in performing emergency skills (12 skills), with scoring system from 1-4. 1= I don't know where to start skills (fail to start), 2= I will do only if no one else is available (acceptable), $3=\mathrm{I}$ will attempt in most cases (very good), and $4=\mathrm{I}$ will attempt in all cases (excellent). B- How many emergency cases seen in last 12 months (12 conditions): zero, 1-2, and 3 or more cases.

C- Satisfaction of the PHC physicians with the emergency services provided at PHC center (12 conditions) with scoring on likert scale from 1 to 5.

The scale 1: means I am satisfied with the facilities, equipment, trained health care personnel and medications available to deal with such cases (totally satisfied). 2: means I am satisfied with the facilities, equipment and medications but we need more training for health care personnel (physicians and nurses) when dealing with such cases (unsatisfied with training). 3: means I am satisfied with the facilities, equipment and trained health care personnel but medications are deficient when dealing with such cases (unsatisfied with medication). 4: means I am satisfied with the medications and trained personnel but facilities and equipment are deficient when dealing with such cases (unsatisfied with equipment and facilities). Finally; 5: means I am overall unsatisfied about the services provided at our PHC center when dealing with such cases (totally unsatisfied). The questionnaire faced validity in previous research at Jeddah, Saudi Arabia, with acceptable reliability ${ }^{(12) .}$

\section{Ethical considerations:}

Informed consent was obtained from the participants after explaining the objectives of the research. The questionnaires were anonymous but had code numbers. Confidentiality of data was maintained and the physicians were free to accept or not to participate in the research.

\section{Statistical methods:}

The collected data were analyzed using Statistical Package for Social Sciences (SPSS 24.0). Descriptive statistics: qualitative data were presented in frequencies and percentages and quantitative data were presented in median (interquartile range), 
mean (SD), and mean ranks. Data were tested for normality using Shapiro Wilk test, and suitable non-parametric tests (Mann Whitney test and Kruskal Wallis tests) were used to test the relationship between physicians' factors with perceived level of competency in emergency skills. Tests were two tailed and $\mathrm{P}$ value was considered significant if $<0.05$.

\section{Results:}

This study was conducted on 35 family physicians, working in family practice centers, the physicians' age ranged from 25-46 years, median (IQR) was 31(28-35) years; most of them were females $(85.7 \%)$, and only $8.6 \%$ qualified with master degree. About training in emergency $51.4 \%$ of them did not attend basic life support course, while $80.0 \%$ and $77.1 \%$ did not attend ACLS or ATLS course respectively. Majority of the sample have experience in emergency services (74.3\%), and 51.4 $\%$ worked for more than 5 years in primary health care (Table - 1).

Table (2) shows perceived level of competency in performing emergency skills, regarding cardiac compression and mouth-to- mouth resuscitation about half (45.7\%) will do it only if no one else is available, while bag and mask resuscitation, and inserting IV cannula only $37.1 \%$ of physicians will do if no one else is available. Most of the sample $74.3 \%$ and $82.9 \%$ do not know where to start regarding intubation or defibrillation respectively. About one third (34.3\%) of the sample will attempt reading ECG, nebulizing or oxygen therapy in most cases. Also $34.3 \%$ of the sample will attempt simple suture in all cases. About half of participants (54.3, and 48.6\%) don't know where to start regarding naso-gastric tube or urinary catheter insertion. Finally; $37.1 \%$ of physicians will attempt to use IV fluids and medications in most of cases (Table - 2).

Table (3) shows the prevalence of emergency cases seen in last 12 months; about $60 \%$ of physicians had seen 3 or more cases of acute asthma, while only $20 \%$ of physicians had seen 3 or more cases of myocardial infarction. More than one third of the sample (40\%) has seen 1 or 2 cases of angina, while majority of them (80\%) have not seen cardiac arrest, about more than half $(60 \%)$ have not seen severe dehydration, while $8.6 \%$ have seen 3 or more cases. About half of physicians $(51.4 \%)$ have seen 3 or more cases of renal colic, while $51.4 \%$ have not seen a case of acute GIT bleeding. About $42.9 \%$ of physicians have seen 1 or 2 cases of hypoglycemia, while $14.3 \%$ of them have seen 3 or more cases of diabetic ketoacidosis. About two thirds $68.6 \%$ 
didn't see a case of convulsions, and 71.4 didn't see a case of anaphylaxis; however $48.6 \%$ of physicians have seen 3 or more cases of vaginal bleeding.

Table (4) shows the highest rate of satisfaction with all emergency services provided at family practice centers (facilities, equipment, trained personnel and medications) as reported in dealing with hypoglycemia cases by third of physicians (28.6\%), followed by renal colic by one quarter of physicians $(25.7 \%)$ then acute vaginal bleeding by (20.0\%) of physicians, whereas the lowest rates were reported in dealing with cases of cardiac arrest and diabetic ketoacidosis in (2.9\%) of study sample.

Regarding acute GIT bleeding, anaphylaxis, or convulsions only (5.7\%) of physicians were satisfied, about severe dehydration only (8.6\%) of physicians were satisfied, acute asthma and angina pectoris (11.4\%), while myocardial infarction service satisfied only (14.3\%). On contrary, the highest rate of dissatisfaction with all emergency services provided at centers were reported in dealing with cardiac arrest (77.1\%), followed by acute GIT bleeding (51.4\%), then myocardial infarction, angina, severe dehydration, and anaphylaxis (40.0\%).

Dissatisfaction with trained personnel (physicians and nurses), the highest rates reported in dealing with cases of acute asthma (42.9\%), convulsions (31.4\%), renal colic, and acute vaginal bleeding (28.6\%), severe dehydration (25.7\%), followed by angina, and hypoglycemia (20.0\%). Dissatisfaction with availability of medications, the highest rates were reported in cases of acute asthma (25.7\%), renal colic, hypoglycemia, and anaphylaxis (22.9\%), then angina 20.0\%, myocardial infarction, diabetic ketoacidosis, and convulsions (17.1\%). Concerning the dissatisfaction with facilities and equipment, the highest rates were reported in cases of diabetic ketoacidosis $(28.6 \%)$, convulsions $(20 \%)$, acute GIT or vaginal bleeding (17.1\%).

Table (5) shows that males reported higher score of perceived level of competence in performing emergency skills scale (mean rank=27.30), than females (mean rank=16.45), and the difference was statistically significant, $\mathrm{p}=0.028$. Physicians hold a master degree reported higher score of perceived level of competence in performing emergency skills scale (mean rank=32.83) whereas those with Medical bachelors and bachelors of surgery (MBBS) reported lower score (mean rank=16.61), and the difference was statistically significant, $\mathrm{P}=0.009$. Physicians attended ACLS ( $<1$ year) reported highest score of perceived level of competence in performing emergency skills scale (mean rank=31.0), followed by 1-2 years (mean 
rank=28.0), then $>2$ years (mean rank=27.0), and finally who not attend at all (mean rank=16.0), and the difference was statistically significant, $\mathrm{P}=0.015$.

\section{Discussion:}

This study showed deficits in training of emergency skills to family physicians, as only $48.6 \%$ attended basic life support course, from them $5.7 \%$ attended in less than 1year, while $80.0 \%$ and $77.1 \%$ did not attend ACLS or ATLS course respectively. Only 5.7\% and 8.6\% attended ACLS and ATLS respectively in last year. In contrary another study in Saudi Arabia, authors reported that primary health care physicians who attended basic life support (BLS) courses (97.1\%) which is higher than our study may be due to the cost of the courses and deficits of workshops in this domain. Similarly (83.5\%) had not attended ATLS courses, with $60.7 \%$ never attending ACLS course relatively similar to this study. It might be attended by specialists of emergency department and other specialties other than family medicine. ${ }^{(12)}$ Also, 46.1\% attended BLS in the last year, whereas 6.8\% and 5.3\% had attended ACLS and ATLS last year, respectively, which is similar to this study. ${ }^{(12)}$ So, there is deficit in training area of emergency and there is a need for training.

Majority of the sample have experience in emergency services (74.3\%), similarly in another study $72.3 \%$ of physicians had previous experience in hospitals emergency departments. ${ }^{(12)}$ This could be explained by exposure to emergency cases in the year of training after graduation to all medical students, which plays an important role in their experience.

Another previous study in Egypt reported that $52.9 \%$ of physicians are in great need for knowledge in emergency care and $76.5 \%$ of physicians in high need for training in emergency care. $^{(13)}$ Regarding perceived level of competency in performing emergency skills less than one third of physicians will attempt to do skills in all emergency cases. In our study only $25.7 \%$ will perform nebulization and oxygen therapy in all cases, in contrary similar studies reported 50.5\% will perform nebulization and oxygen therapy in all cases, while the study showed that $34.3 \%$ will perform simple suture in all cases, in contrary $44.2 \%$ will perform simple suture in all cases in comparable study. This could be explained by lack of training in these skills, besides deficiency of exposure to such cases.

Also $22.9 \%$ of physicians will attempt cardiac compression versus $38.8 \%$ in comparable study, bag and mask resuscitation only $20 \%$ of physicians will perform, versus $37.9 \%$ in comparable study, and physicians using intravenous (IV) fluid \& 
medications in $28.6 \%$ versus $36.4 \%$ in all cases. Also $31 \%$ will read ECG for all cases versus $67 \%$ in another study. ${ }^{(12)}$ This could be explained by deficient training in these skills, besides lack of exposure to such cases, most of emergency cases go directly to hospital, instead of family practice centers availability.

However, another study in Egypt showed that only $5.9 \%$ of physicians felt that they were not competent to deal with emergency cases, and $76.5 \%$ were more competent, this may be due to general survey that was done regarding self-confidence not for each item as in this study. ${ }^{(13)}$

Regarding emergency cases seen in last 12 months, the most common cases were acute asthma, renal colic, and vaginal bleeding, These results were similar to study in Saudi Arabia but fewer cases than our study. ${ }^{(12)}$ This could reflect nature of cases seen in emergency care in primary health care to be targeted in training courses.

The highest rate of satisfaction with all emergency services provided at family practice centers were reported in dealing with hypoglycemia, followed by renal colic. This could be explained by feasibility and affordability of management of such health problems at the level of family practice. Also, the family physician can afford such service with the acquired skill during his/her training. Acute vaginal bleeding came at a lower rank of satisfaction. It is a common practice and physicians are competent in handling it to a great extent. Training in women health is mandatory in postgraduate programs ( master and medical doctorate). The lowest rates of satisfaction were reported in dealing with cases of cardiac arrest and diabetic ketoacidosis, acute GIT bleeding, anaphylaxis, convulsions, severe dehydration, acute asthma and angina pectoris, and myocardial infarction. In another study, satisfaction was higher than our study especially in cases of acute asthma, renal colic, and severe dehydration. ${ }^{(12)}$ This reflects deficiency in training of physicians on guidelines, deficiency of instruments, and drugs which needed in emergency cases to improve satisfaction of physicians regarding emergency services. This may be lower socioeconomic status in Egypt and cost of these services that make them not available in centers, so physicians are unsatisfied.

In a comparable study acute asthma was the highest rate of satisfaction with all emergency services, followed by renal colic, and hypoglycemia ${ }^{(14)}$ also due to few skills needed and availability of low cost treatment to these cases. Another study in Egypt about satisfaction of patients in emergency services, $35.7 \%$ was satisfied with the emergency services provided by the PHC facilities. However, $64.3 \%$ were 
dissatisfied $^{(13)}$, also due to scarce resources in primary health care and lack of training of PHC physicians as most of them unqualified by postgraduate studies or courses, as most of them newly graduated doctors without previous experience.

In this study; males reported higher score of perceived level of competency in performing emergency skills scale; it was insignificant in another study, ${ }^{(12)}$ this may be due to more interest of males in emergency training and practicing more than females. Physicians hold a master degree reported higher score of perceived level of competency, similar to another study showed that qualification is related to perceived competency. ${ }^{(12)}$ Physicians who had attended ACLS ( $<1$ year) reported highest score of perceived level of competency in performing emergency skills, in another study it is not significant. ${ }^{(12)}$ As it is easy to remember training if taken from less than one year, this reflects the importance of continues medical education and evaluation.

\section{Study limitations:}

Limitations of the study were in the form of small sample, sampling technique which is convenience without randomization, and scarcity of comparable studies.

\section{Conclusions:}

There is a deficit in perceived competency in performing emergency skills among family physicians, and high dissatisfaction with current emergency services due to lack of training, scarce resources as instruments and drugs in family practice centers. There is need for more training courses as BLS, ACLS, and ATLS for family physicians.

\section{Conflict of Interest:}

There is no conflict of interest.

\section{References:}

1. Mahler H. Present status of WHO's initiative: Health for all by 2000. Annual review of public health 1988; 9: 71-77.

2. Rafeh N. Accreditation of primary health care facilities in Egypt: Program policies and procedures. Technical report No. 65. Bethesda, MD: Partnerships for Health Reform Project, Abt Associates Inc., 2001.

3. Yorganci M, Yaman H. Preparedness of primary healthcare centers for critical emergency situations in southwest Turkey. Prehosp Disaster Med. 2008;23(4):342-345.

4. Klig J. E, O’Malley P. J. Pediatric office emergencies. Curr Opin Pediatr. 2007;19(5):591-596. 
5. Mahfouz A. A, Abdelmoneim I, Khan M. Y, Daffalla A. A, Diab M. M, El-Gamal M. N, Al-Sharif A. Primary health care emergency services in Abha district of southwestern Saudi Arabia. East Mediterr Health J. 2007;13(1):103-112.

6. WHO, Primary Health Care approach in emergencies. Report of a regional meeting Dhaka, Bangladesh, 28-30 September, 2010;1-35.

7. World Bank. Egypt - Management and service quality in primary health care facilities in the Alexandria and Menoufa governorates, world bank, Washington, DC 2010. Available at: http://documents.worldbank.org/curated/en/814731468021569255/Egyptmanagement-and-service-quality-in-primary-health-care-facilities-in-theAlexandria-and-Menoufia-governorates

8. Hansen PM, Peters DH, Viswanathan K, Rao KD, Mashkoor A, Burnham G. Client perceptions of the quality of primary care services in Afghanistan. Int $\mathbf{J}$ Qual Health Care. 2008; 6: 1-8.

9. Ramanayake RB, Ranasingha S, Lakmini S. Management of emergencies in general practice: Role of general practitioners. J Fam Med Prim Care 2014; 3: 305-308.

10. Becker J, Dell A, Jenkins L, Sayed R. Reasons why patients with primary health care problems access a secondary hospital emergency center. S Afr Med J 2012; 102: 800-801.

11. Jacques A, Emergency Medicine: Primary-Care Medicine, Can Fam Physician. 1987 Dec; 33: 2681-2682.

12. Aloufi, M.A., Bakarman, M.A. Barriers Facing Primary Health Care Physicians When Dealing with Emergency Cases in Jeddah, Saudi Arabia. Glob. J. Health Sci., 2015;8:192.

13. Mohey, A. Primary Healthcare Emergency Services in Alexandria, Egypt 2016. Qual. Prim. Care, 2017; 25: 303-315.

14. Savoia, E., Lin, L., Bernard, D., Klein, N., James, L.P., Guicciardi, S. Public Health System Research in Public Health Emergency Preparedness in the United States (2009-2015): Actionable Knowledge Base. Am. J. Public Health, 2017;107: e1-e6. 
Table (1): Personal characteristics, training and previous experience of the study sample $(\mathbf{n}=35)$

\begin{tabular}{|c|c|c|}
\hline Physicians' factors & Frequency & $\%$ \\
\hline $\begin{array}{l}\text { Age (Years) } \\
\text { - } 20-<30 \\
\text { : } 30-<40 \\
\text { Mean (SD) }\end{array}$ & $\begin{array}{c}12 \\
22 \\
1 \\
31.7(4.7)\end{array}$ & $\begin{array}{c}34.3 \\
62.9 \\
2.9\end{array}$ \\
\hline $\begin{aligned} \text { Gender } & \\
\text { - } & \text { Male } \\
\text { - } & \text { Female }\end{aligned}$ & $\begin{array}{c}5 \\
30 \\
\end{array}$ & $\begin{array}{l}14.3 \\
85.7\end{array}$ \\
\hline $\begin{array}{l}\text { Qualification } \\
\text { - } \mathrm{MBBS}^{1} \text { (in master) } \\
\text { - } \quad \text { Master degree (in MD) }\end{array}$ & $\begin{array}{c}32 \\
3\end{array}$ & $\begin{array}{c}91.4 \\
8.6\end{array}$ \\
\hline $\begin{aligned} \text { BLS }^{2} & \\
\text {. } & <1 \text { year } \\
\text { - } & 1-2 \text { years } \\
\text { - } & >2 \text { years } \\
\text { - } & \text { Don't attend at all }\end{aligned}$ & $\begin{array}{c}2 \\
1 \\
14 \\
18\end{array}$ & $\begin{array}{c}5.7 \\
2.9 \\
40.0 \\
51.4\end{array}$ \\
\hline $\begin{aligned} & \text { ACLS }^{3} \\
& \text { - }<1 \text { year } \\
& \text { - } 1-2 \text { years } \\
& \text { - }>2 \text { years } \\
& \text { - } \text { Don't attend at all }\end{aligned}$ & $\begin{array}{c}1 \\
2 \\
4 \\
28\end{array}$ & $\begin{array}{c}5.7 \\
2.9 \\
11.4 \\
80.0\end{array}$ \\
\hline $\begin{aligned} \text { ATLS }^{4} & \\
\text { - } & <1 \text { year } \\
\text { - } & 1-2 \text { years } \\
\text { - } & >2 \text { years } \\
\text { - } & \text { Don't attend at all }\end{aligned}$ & $\begin{array}{c}3 \\
2 \\
3 \\
27\end{array}$ & $\begin{array}{r}8.6 \\
5.7 \\
8.6 \\
77.1\end{array}$ \\
\hline $\begin{array}{c}\text { Experience } \\
\text { - Yes } \\
\text { - } \quad \text { No } \\
\end{array}$ & $\begin{array}{c}26 \\
9\end{array}$ & $\begin{array}{l}74.3 \\
25.7\end{array}$ \\
\hline $\begin{array}{c}\text { Years of working in } \mathrm{PHC}^{5} \\
\text {. } \quad<1 \text { year } \\
\text {. } 1-5 \text { years } \\
\text {. }>5 \text { years }\end{array}$ & $\begin{array}{c}3 \\
14 \\
18\end{array}$ & $\begin{array}{c}8.6 \\
40 \\
51.4\end{array}$ \\
\hline
\end{tabular}

${ }^{1}$ Bachelor of Medicine/ Bachelor of Surgery ${ }^{2}$ Basic Life Support ${ }^{3}$ Advanced Cardiac Life Support ${ }^{4}$ Advanced Trauma Life Support ${ }^{5}$ Primary Health Care. MD: Medical Doctorate 
Table (2): Perceived level of competency in performing skills $(n=35)$

\begin{tabular}{|c|c|c|c|c|c|c|c|c|}
\hline \multirow{2}{*}{ Skills } & \multicolumn{2}{|c|}{ Fail to start } & \multicolumn{2}{|c|}{ Acceptable } & \multicolumn{2}{|c|}{ Very good } & \multicolumn{2}{|c|}{ excellent } \\
\hline & $\mathbf{N}$ & $\%$ & $\mathbf{N}$ & $\%$ & $\mathbf{N}$ & $\%$ & $\mathbf{N}$ & $\%$ \\
\hline - Cardiac compression & 5 & 14.3 & 16 & 45.7 & 6 & 17.1 & 8 & 22.9 \\
\hline $\begin{array}{l}\text { - } \begin{array}{l}\text { Mouth to mouth } \\
\text { resuscitation }\end{array}\end{array}$ & 8 & 22.9 & 16 & 45.7 & 5 & 14.3 & 6 & 17.1 \\
\hline $\begin{array}{l}\text { Bag and Mask } \\
\text { Resuscitation }\end{array}$ & 10 & 28.6 & 13 & 37.1 & 5 & 14.3 & 7 & 20.0 \\
\hline - Inserting IV cannula & 5 & 14.3 & 13 & 37.1 & 13 & 37.1 & 4 & 11.4 \\
\hline - Intubation & 26 & 74.3 & 7 & 20.0 & 1 & 2.9 & 1 & 2.9 \\
\hline - Defibrillation & 29 & 82.9 & 5 & 14.3 & 0 & 0 & 1 & 2.9 \\
\hline - Reading ECG* & 2 & 5.7 & 10 & 28.6 & 12 & 34.3 & 11 & 31.4 \\
\hline $\begin{array}{l}\text { Nebulization and } \\
\text { Oxygen Therapy }\end{array}$ & 5 & 14.3 & 9 & 25.7 & 12 & 34.3 & 9 & 25.7 \\
\hline - Simple Suture & 5 & 14.3 & 8 & 22.9 & 10 & 28.6 & 12 & 34.3 \\
\hline - $\mathrm{NGT}^{* *}$ Insertion & 19 & 54.3 & 8 & 22.9 & 6 & 17.1 & 2 & 5.7 \\
\hline $\begin{array}{l}\text { Urinary Catheter } \\
\text { insertion }\end{array}$ & 17 & 48.6 & 12 & 34.3 & 2 & 5.7 & 4 & 11.4 \\
\hline $\begin{array}{l}\text { - Using IV Fluids and } \\
\text { medications }\end{array}$ & 7 & 20.0 & 5 & 14.3 & 13 & 37.1 & 10 & 28.6 \\
\hline
\end{tabular}

Table (3): Cases seen in last 12 months by study sample ( $(\mathrm{n}=\mathbf{3 5})$

\begin{tabular}{|l|c|c|c|c|c|c|}
\hline \multirow{2}{*}{ Type of emergency case } & \multicolumn{2}{|c|}{$\mathbf{0}$} & \multicolumn{2}{|c|}{$\mathbf{1 - 2}$} & \multicolumn{2}{c|}{$\geq \mathbf{3}$} \\
\cline { 2 - 7 } & $\mathbf{N}$ & $\mathbf{\%}$ & $\mathbf{N}$ & $\mathbf{\%}$ & $\mathbf{N}$ & $\mathbf{\%}$ \\
\hline - Acute asthma & 3 & 8.6 & 11 & 31.4 & 21 & 60.0 \\
\hline - Myocardial infarction & 14 & 40.0 & 14 & 40.0 & 7 & 20.0 \\
\hline - Angina pectoris & 13 & 37.1 & 14 & 40.0 & 8 & 22.9 \\
\hline - Cardiac arrest & 28 & 80.0 & 4 & 11.4 & 3 & 8.6 \\
\hline - Severe dehydration & 21 & 60.0 & 11 & 31.4 & 3 & 8.6 \\
\hline - - Renal colic & 2 & 5.7 & 15 & 42.9 & 18 & 51.4 \\
\hline - Acute GIT Bleeding & 18 & 51.4 & 15 & 42.9 & 2 & 5.7 \\
\hline - Hypoglycemia & 11 & 31.4 & 15 & 42.9 & 9 & 25.7 \\
\hline - Diabetic ketoacidosis & 17 & 48.6 & 13 & 37.1 & 5 & 14.3 \\
\hline - Convulsions & 24 & 68.6 & 10 & 28.6 & 1 & 2.9 \\
\hline - Anaphylaxis & 25 & 71.4 & 9 & 25.7 & 1 & 2.9 \\
\hline - Acute vaginal bleeding & 7 & 20.0 & 11 & 31.4 & 17 & 48.6 \\
\hline
\end{tabular}


Table (4): Satisfaction of family physicians with the emergency services provided at Family Practice centers (FPCs) $(n=35)$

\begin{tabular}{|c|c|c|c|c|c|}
\hline \multirow[t]{2}{*}{ Emergency condition } & \multicolumn{5}{|c|}{ Satisfaction with the emergency services provided at FPCs } \\
\hline & $\begin{array}{c}\text { Totally } \\
\text { satisfied } \\
\mathbf{N}(\%)\end{array}$ & $\begin{array}{c}\text { Unsatisfied } \\
\text { with } \\
\text { training } \\
\mathbf{N}(\%)\end{array}$ & $\begin{array}{l}\text { Unsatisfied } \\
\text { with } \\
\text { medication } \\
\mathrm{N}(\%)\end{array}$ & $\begin{array}{l}\text { Unsatisfied } \\
\text { with } \\
\text { equipment } \\
\text { and } \\
\text { facilities } \\
N(\%)\end{array}$ & $\begin{array}{c}\text { Totally } \\
\text { unsatisfied } \\
\mathbf{N}(\%)\end{array}$ \\
\hline - $\quad$ Acute asthma & $4(11.4)$ & $15(42.9)$ & $9(25.7)$ & $2(5.7)$ & $5(14.3)$ \\
\hline - Myocardial infarction & $5(14.3)$ & $6(17.1)$ & $6(17.1)$ & $4(11.4)$ & $14(40.0)$ \\
\hline - Angina pectoris & $4(11.4)$ & $7(20.0)$ & $7(20.0)$ & $3(8.6)$ & $14(40.0)$ \\
\hline - Cardiac arrest & $1(2.9)$ & $2(5.7)$ & $3(8.6)$ & $2(5.7)$ & $27(77.1)$ \\
\hline - $\quad$ Severe dehydration & $3(8.6)$ & $9(25.7)$ & $4(11.4)$ & $5(14.3)$ & $14(40.0)$ \\
\hline - Renal colic & $9(25.7)$ & $10(28.6)$ & $8(22.9)$ & $5(14.3)$ & $3(8.6)$ \\
\hline - Acute GIT Bleeding & $2(5.7)$ & $5(14.3)$ & $4(11.4)$ & $6(17.1)$ & $18(51.4)$ \\
\hline - Hypoglycemia & $10(28.6)$ & $7(20.0)$ & $8(22.9)$ & $3(8.6)$ & $7(20.0)$ \\
\hline - $\quad$ DKA & $1(2.9)$ & $6(17.1)$ & $6(17.1)$ & $10(28.6)$ & $12(34.3)$ \\
\hline - Convulsions & $2(5.7)$ & $11(31.4)$ & $6(17.1)$ & $7(20.0)$ & $9(25.7)$ \\
\hline - Anaphylaxis & $2(5.7)$ & $6(17.1)$ & $8(22.9)$ & $5(14.3)$ & $14(40.0)$ \\
\hline - Acute vaginal bleeding & $7(20.0)$ & $10(28.6)$ & $4(11.4)$ & $6(17.1)$ & $8(22.9)$ \\
\hline
\end{tabular}


Table (5): Relation between physicians' factors and perceived level of competency of skills (score 12-48)

\begin{tabular}{|c|c|c|c|}
\hline Physicians factors & Median (IQR) & Mean rank & P value \\
\hline $\begin{array}{c}\text { Age (Years) } \\
\cdot \quad<30 \\
. \quad 30-\end{array}$ & $\begin{array}{l}27(23.0-34.5) \\
27(19.0-33.0)\end{array}$ & $\begin{array}{l}19.25 \\
17.35\end{array}$ & $0.601 *$ \\
\hline $\begin{aligned} \text { Gender } & \\
\text { - } & \text { Male } \\
\text { - } & \text { Female }\end{aligned}$ & $\begin{array}{c}34(27.5-41.0) \\
23.5(19.75-32.25)\end{array}$ & $\begin{array}{l}27.30 \\
16.45\end{array}$ & $.028 *$ \\
\hline $\begin{array}{l}\text { Qualification } \\
\text { - } \text { MBBS }^{1} \\
\text { - } \quad \text { Master degree }\end{array}$ & $\begin{array}{c}25.5(20.0-31.50) \\
37.0(36.0-42.0)\end{array}$ & $\begin{array}{l}16.61 \\
32.83\end{array}$ & $.009 *$ \\
\hline $\begin{aligned} \text { BLS }^{2} & \\
\text { - } & <1 \text { year } \\
\text { - } & 1-2 \text { years } \\
\text { - } & >2 \text { years } \\
\text { - } & \text { Don't attend at all }\end{aligned}$ & $\begin{array}{c}32.0(28.0-36.0) \\
35.0(35.0-35.0) \\
29.5(23.0-34.75) \\
22.5(19.0-27.75)\end{array}$ & $\begin{array}{c}26.0 \\
29.5 \\
21.50 \\
13.75\end{array}$ & $0.065 * *$ \\
\hline $\begin{aligned} \text { ACLS }^{3} & \\
\text { - } & <1 \text { year } \\
\text { - } & 1-2 \text { years } \\
\text { - } & >2 \text { years } \\
\text { - } & \text { Don't attend at all }\end{aligned}$ & $\begin{array}{c}36.0(36.0-36.0) \\
34.0(33.0-35.0) \\
33.0(27.5-40.75) \\
23.0(19.25-30.0)\end{array}$ & $\begin{array}{c}31.0 \\
28.0 \\
27.0 \\
15.54\end{array}$ & $0.015 * *$ \\
\hline $\begin{array}{l}\text { ATLS }^{4} \\
\text { - } \quad<1 \text { year } \\
\text { - } 1-2 \text { years } \\
\text { - } \quad>2 \text { years } \\
\text { - } \quad \text { Don't attend at all }\end{array}$ & $\begin{array}{l}33.0(28.0-36.0) \\
29.0(23.0-35.0) \\
29.0(27.0-42.0) \\
23.0(19.0-32.0)\end{array}$ & $\begin{array}{l}26.17 \\
21.50 \\
25.17 \\
16.04\end{array}$ & $0.208 * *$ \\
\hline $\begin{array}{c}\text { Experience } \\
\text { - Yes } \\
\text { - } \mathrm{No}\end{array}$ & $\begin{array}{c}27.0(19.75-33.25) \\
30.0(21.5-34.0)\end{array}$ & $\begin{array}{l}17.42 \\
19.67\end{array}$ & $.570 *$ \\
\hline $\begin{array}{c}\text { Years working in } \mathrm{PHC}^{5} \\
\text {. } \quad<1 \text { year } \\
\text {. } 1-5 \text { years } \\
\text {. }>5 \text { years }\end{array}$ & $\begin{array}{c}29.0(23.0-35.0) \\
25.0(18.5-33.5) \\
27.0(20.75-33.25)\end{array}$ & $\begin{array}{l}21.67 \\
16.32 \\
18.69\end{array}$ & $0.655^{* *}$ \\
\hline
\end{tabular}


الملخص العربي

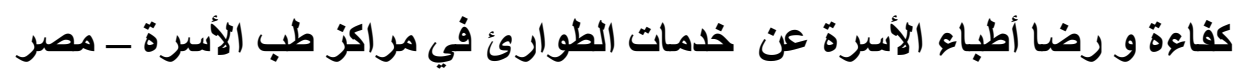

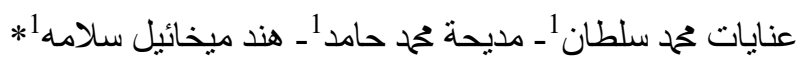

الخلفيه: تقدم مر اكز الر عاية الصحية الأولية الرعاية لعدد كبير من المو اطنين. وتعرف منظمة الصحة العالمية

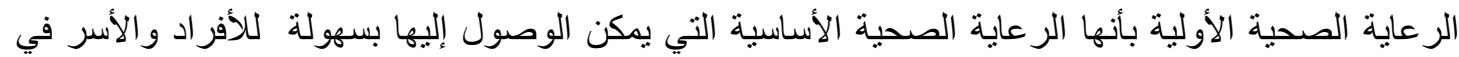

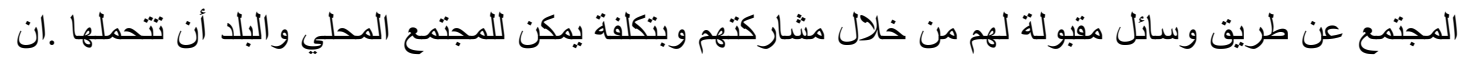
الرعاية الصحية الأولية تشمل خدمات مثل تنظيم الأسرة ورعاية الأمومة ورعاية الطفل ورعاية الأسنان و الخدمات التعليمية الصحية ومكافحة الأمر اض المعدية وخدمات الرعاية الصحية في حالات الطو ارئ و الصحة البيئية. في الو اقع ان نسبه 90٪ من حالات الطوارىء يمكن التعامل معها تماما من قبل أطباء الأسرة المؤهلين.

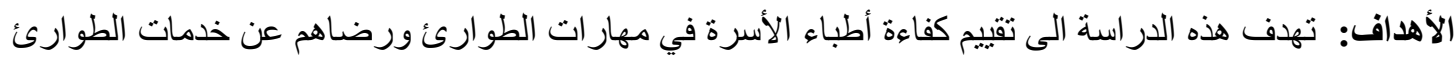
في مر اكز طب الأسرة. المنهجيه وطرق البحث: كان عدد المشاركين فى البحث 35 من اطباء الاسرة باستخدام استبيان شمل بعض العوامل فى الاطباء كالعمر و التنريب على مهار ات الطو ارئ و كفاءه الاطباء فى مهار ات الطو ارئو رضاهم عن خدمات الطو ارئ بالمر اكز الطبية. النتائج : اظهرت الدراسه بان متوسط عمر الأطباء 31 سنة ومعظمهم من الإناث (85,7 \%) و 8,6 في المائة فقط حاصلين على درجة الماجستير. كما تبين أن 51,4\% لم يحضروا دورة إنعاش الحياة الأساسية، في حين أن نسبة كبيرة لم يحضروا دورة الإنعاش المتقدمة و وله

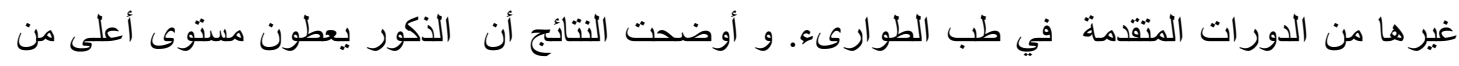

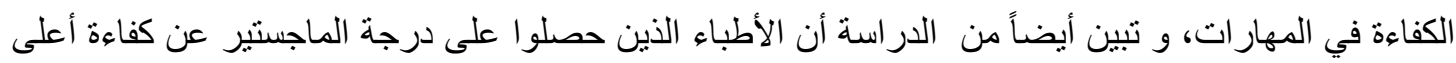
في أداء مهار ات الطوارئ.

الخلاصه:خلصت الدراسة أن هنالك نقص في كفاءة أداء مهارات الطوارئ لاى أطباء الأسرة، وعدم الرضا الثديد عن خدمات الطوارئ الحالية. أيضا هناك حاجة لمزيد من الدورات التدريبية المتقدمة في طب الطوارىء و توفير الادويه و المستلزمات بالمر اكز. 